\title{
Pengaruh Faktor Predisposisi, Faktor Pendorong Dan Faktor Pendukung Terhadap Pencatatan Rekam Medis di RSUD Dr. RM Djoelham Binjai
}

\author{
Giyatno $^{1}$, Megawati ${ }^{2}$ \\ ${ }^{1}$ Mahasiswa Pascasarjana Institut Kesehatan Helvetia Medan \\ ${ }^{2}$ Dosen Pascasarjana Institut Kesehatan Helvetia Medan
}

\begin{tabular}{l}
\hline \hline Article Info \\
\hline Article history: \\
Received Jun 30, 2021 \\
Revised Jul 19, 2021 \\
Accepted Jul 26, 2021 \\
\hline
\end{tabular}

Keywords:

Predisposing Factors

Drivers

Supporting Medical Record

Recording

\begin{abstract}
ABSTRAK
Law of the Republic of Indonesia number: 29 of 2004 concerning Medical Practice, which includes the obligation of doctors and dentists to make medical records. The results of the evaluation of the completeness of medical records in RSUD Dr. RM Djoelham Binjai still found incomplete medical record files. This study aims to determine the effect of predisposing factors (knowledge, attitudes), driving factors (support from other officers) and supporting factors (facilities and facilities, regulations) on the behavior of doctors in recording medical records. The research design used in this study was a descriptive analytic survey with a cross sectional design, a sample of 29 doctors and quantitative data analysis with univariate, bivariate and multivariate analysis. Based on the results of the chi square test, it was obtained that Knowledge variable $\mathrm{p}=0.001$, Attitude power $\mathrm{p}$ $=0.002$, other support staff $\mathrm{p}=0.000$, facilities and facilities $\mathrm{p}=$ 0.002 and settings $p=0.007$ multivariate test showed that of the 5 variables tested multiple logistic regression showed variable which has a p-value $>0.05$. Based on the results of the multiple logistic regression test, the significant value of the model together was obtained at $0.002<0.05$, which means that the four variables used as models have a significant influence on Medical Record Recording, the factor that has the greatest influence on Medical Record Recording is the Support Personnel variable. Others are indicated by an OR value of 0.062 . The conclusion in this study is that there is an influence, Knowledge, Attitude, Support of Other Personnel, Facilities and Facilities, and Regulations on the Completeness of Medical Record Recording. It is hoped that doctors do not delay in recording complete medical records.
\end{abstract}

\section{Corresponding Author:}

This is an open access article under the $\underline{C C B Y-S A l i c e n s e .}$

Giyatno,

Program Studi Pascasarjana Ilmu Kesehatan Masyarakat,

Institut Kesehatan Helvetia Medan,

Jl. Sumarsono No.107, Helvetia, Kec. Sunggal, Kabupaten Deli Serdang, Sumatera Utara 20124.

Email: agicida@gmail.com 


\section{PENDAHULUAN}

Berkas rekam medis mulai mendapat perhatian sejak dikeluarkannya Peraturan Pemerintah No. 10 tahun 1960. Isi peraturan ini mewajibkan semua petugas kesehatan melakukan pendokumentasian yang sifatnya merupakan rahasia pasien dan rahasia kedokteran. Kemudian pada tahun 1972 dikeluarkan Surat Keputusan Menteri Kesehatan RI No. 034/Birhup/1972, isi ini makin menegaskan bahwa rumah sakit berkewajiban untuk menyelenggarakan rekam medis. Pada Bab I pasal 3 Surat Keputusan tersebut dinyatakan bahwa guna menunjang terselenggaranya rencana induk yang baik, maka setiap rumah sakit harus mempunyai dan merawat statistik yang up to date serta membuat Medical Record berdasarkan ketentuan-ketentuan yang telah ditetapkan [1].

Sejalan dengan peraturan ini maka Direktorat Jenderal Pelayanan Medik telah mengeluarkan pedoman penyelenggaraan dan prosedur rekam medis rumah sakit di Indonesia Revisi II yang merupakan revisi dari pedoman pengelolaan Rekam medis Rumah Sakit sesuai dengan Surat Keputusan Direktur Jenderal Pelayanan Medik Nomor YM 00.03.2.2.1996 tanggal 27 Nopember 1996 [2].

Keharusan adanya rekam medis didukung oleh terbitnya Undang- Undang RI Nomor: 29 Tahun 2004 tentang Praktik Kedokteran yang dikeluarkan tanggal 6 Oktober 2004. Dalam Undang-Undang ini pada pasal 46 ayat satu disebutkan "Setiap dokter atau dokter gigi dalam menjalankan praktiknya wajib membuat rekam medis" [3].

Undang-undang nomor 44 tahun 2009 tentang rumah sakit juga menegaskan bahwa rumah sakit berkewajiban menyelenggarakan rekam medis dan diberikan sanksi bagi rumah sakit yang tidak menyelenggarakan rekam medis berupa sanksi administratif berupa teguran, teguran tertulis atau denda dan pencabutan izin rumah sakit [4].

Gita Kencana (2019) menyatakan seluruh dokter dan petugas PPA di RS X memahami tentang rekam medis, kelengkapannya serta pentingnya berkas tersebut bagi suatu rumah sakit, dan beberapa mengetahui SPO yang ada, walaupun sosialisasi tentang SPO penulisan rekam medis belum menyeluruh namun seluruh responden mengetahui cara-cara penulisan rekam medis yang baik secara umum. Desain rekam medis di RS ini sudah cukup baik, walaupun masih terdapat beberapa point yang dianggap tidak perlu untuk dicantumkan, sehingga membuat dokter malas mengisi. Tanggung jawab dari petugas dalam pengisian berkas rekam medis masih dapat dikatakan kurang, ini dikatakan karena masih terdapat dokter maupun perawat yang tidak mengisi rekam medis dengan lengkap, walaupun sebenarnya para responden tahu dan mengerti tentang rekam medis, ini dikarenakan belum adanya sistem pemberian reward dan punishment, sehingga mereka menganggap bila selama ini ada kekurangan dalam mengisi rekam medis itu bukanlah suatu masalah, serta masih diperlukan dukungan rekan, baik yang didapat dari rekan kerja sesama teman sejawat maupun manajemen untuk saling mengingatkan dalam mengisi rekam medis [5].

Made Karma (2019) dalam penelitiannya terdapat beberapa faktor yang mempengaruhi ketidaklengkapan rekam medis pada rumah sakit yang dilihat dari faktor $\mathrm{SDM} /$ manusia, alat, metode, material dan keuangan. Dilihat dari segi SDM/Manusia, faktor penyebabnya adalah pengetahuan petugas yang masih kurang, kedisiplinan petugas, motivasi yang rendah, beban kerja yang cukup tinggi dan komunikasi yang berjalan tidak baik [6].

Hasil pengamatan rekam medis di Puskesmas Grogol dan Sukoharjo oleh Astri Sri Wariyanti terdapat secara umum terdapat peningkatan 4,3\%-10,2\% rata-rata kelengkapan pengisian dokumen rekam medis dari 4 komponen penilaian sebelum-sesudah akreditasi di Puskesmas Sukoharjo dan Grogol [7].

Rumah Sakit Umum Daerah Dr. RM Djoelham Binjai sebagai rumah sakit kelas B, sejak berdiri tahun 1927 telah menyelenggarakan rekam medis. Namun pengisian rekam medis belum seperti yang diharapkan. Hasil evaluasi mengenai kelengkapan rekam medis, 
masih dijumpai berkas rekam medis yang tidak lengkap. Pada tahun 2017 sebanyak 17,37\% dari berkas rekam medis dijumpai tidak lengkap, tahun 2018 sebanyak 25,98\%, sementara tahun 2019 meningkat menjadi sebanyak 40,31\% masih belum lengkap. Ketidaklengkapan rekam medis ini antara lain berupa ketidaksesuaian penulisan diagnosa waktu masuk dan diagnosa pada saat keluar, nama dan tanda tangan dokter tidak tercantum, ketidaklengkapan isian formulir resume medis, lembar edukasi terintegrasi, catatan perkembangan pasien terintegrasi dan lain-lain [8].

Upaya-upaya rumah sakit untuk mengurangi kesalahan dan ketidaklengkapan berkas medik telah dilakukan pembentukan panitia yang berfungsi untuk mengawasi pelaksanaan rekam medis dan memberikan rekomendasi kepada direktur untuk perbaikan kwalitas rekam medis rumah sakit.

Berdasarkan uraian permasalahan di atas, maka yang menjadi permasalahan dalam penelitian ini adalah: Bagaimana pengaruh faktor predisposisi, faktor pendorong dan faktor pendukung terhadap pencatatan rekam medis di RSUD Dr. RM Djoelham Binjai. Penelitian ini bertujuan untuk mengetahui pengaruh faktor predisposisi (pengetahuan, sikap dokter penanggung jawab pasien), faktor pendorong (dukungan petugas lain) dan faktor pendukung (fasilitas dan sarana, peraturan-peraturan) terhadap perilaku dokter dalam pencatatan rekam medis di RSUD Dr. RM Djoelham Binjai.

\section{METODE PENELITIAN}

A. Jenis Penelitian

Jenis penelitan yang digaunakan adalah survei analitik deskriptif dengan rancangan cross sectional. Waktu penelitian dilakukan pada bulan November 2020 sampai dengan selesai. Tempat penelitian ini dilakukan di RSUD Dr. RM Djoelham Binjai, Jalan Sultan Hasanudin no. 09 kota Binjai.

B. Populasi

Populasi penelitian ini adalah seluruh dokter spesialis yang menjadi Dokter Penanggung Jawab Pasien (DPJP) di RSUD Dr. RM Djoelham Binjai yang berjumlah 29 orang.

C. Sampel

Sampel dalam penelitian ini adalah mengambil total populasi, yaitu seluruh dokter spesialis yang menjadi DPJP sebanyak 29 orang.

D. Instrumen Penelitian

Instrumen yang digunakan dalam penelitian ini adalah kuesioner.

E. Cara Pengumpulan Data

\section{Data Primer}

1. Menggunakan Kuesioner Tertutup

Data dikumpulkan dengan cara pengisian kuesioner oleh para responden yaitu: seluruh dokter spesialis RSUD Dr. RM Djoelham yang menjadi sampel. Kuesioner bersifat tertutup yang telah disediakan pilihan jawaban. Kuesioner ini dibuat berdasarkan variabel-variabel penelitian yaitu variabel bebas dan variabel terikat dan isinya bersumber dari Undang-Undang RI Nomor 29 Tahun 2004 tentang Praktek Kedokteran, Peraturan Menteri Kesehatan nomor 269/Menkes/Per/III/2008, dan buku pedoman pelayanan rekam medis RSUD Dr. RM Djoelham Binjai tahun 2017. 
Tabel 1. Aspek Pengukuran Variabel Bebas dan Variabel Terikat

\begin{tabular}{|c|c|c|c|c|}
\hline No & Variabel & Definisi Operasional & Kriteria & Skala ukur \\
\hline \multicolumn{5}{|c|}{ Variabel Bebas } \\
\hline \multicolumn{5}{|c|}{ 1. Faktor Predisposisi } \\
\hline & Pengetahuan & $\begin{array}{l}\text { Pengetahuan adalah pemahaman } \\
\text { dokter spesialis yang sebagai } \\
\text { DPJP tentang rekam medis dan } \\
\text { peraturan-peraturan yang } \\
\text { berkaitan dengan rekam medis }\end{array}$ & $\begin{array}{l}\text { 3. baik } \\
\text { 2. sedang } \\
\text { 1. tidak baik }\end{array}$ & Ordinal \\
\hline & Sikap & $\begin{array}{l}\text { Sikap adalah respon yang masih } \\
\text { tertutup dari para dokter spesialis } \\
\text { yang sebagai DPJP tentang } \\
\text { kelengkapan pencatatan rekam } \\
\text { medis }\end{array}$ & $\begin{array}{l}\text { 3. baik } \\
\text { 2. sedang } \\
\text { 1. tidak baik }\end{array}$ & Ordinal \\
\hline \multicolumn{5}{|c|}{ 2. Faktor Pendorong } \\
\hline & $\begin{array}{l}\text { Fasilitas dan } \\
\text { sarana }\end{array}$ & $\begin{array}{l}\text { Fasilitas dan sarana yang } \\
\text { dimaksud adalah baik sarana fisik } \\
\text { maupun non fisik seperti gedung } \\
\text { atau ruangan, maupun peralatan } \\
\text { lain serta kemungkinan untuk } \\
\text { mendapatkan informasi yang } \\
\text { mendukung dalam pelaksanaan } \\
\text { pencatatan rekam medis }\end{array}$ & $\begin{array}{l}\text { 3. baik } \\
\text { 2. sedang } \\
\text { 1. tidak baik }\end{array}$ & Ordinal \\
\hline \multicolumn{5}{|c|}{ 3. $\quad$ Faktor Pendukung } \\
\hline & $\begin{array}{l}\text { Dukungan } \\
\text { petugas lain }\end{array}$ & $\begin{array}{l}\text { Dukungan petugas lain adalah } \\
\text { adanya kerjasama dari teman } \\
\text { sejawat dokter dalam pelaksanaan } \\
\text { pencatatan rekam medis }\end{array}$ & $\begin{array}{l}\text { 3. baik } \\
\text { 2. sedang } \\
\text { 1. tidak baik }\end{array}$ & Ordinal \\
\hline & Peraturan & $\begin{array}{lr}\text { Peraturan-peraturan } & \text { adalah } \\
\text { Undang-Undang RI Nomor 29 } \\
\text { Tahun 2004 tentang Praktek } \\
\text { Kedokteran, Peraturan } & \text { Menteri } \\
\text { Kesehatan } & \text { nomor } \\
\text { 269/Menkes/III/2008, Pedoman } \\
\text { Pelayanan Rekam Medis di RSUD } \\
\text { Dr. RM Dioelham }\end{array}$ & $\begin{array}{l}\text { 3. baik } \\
\text { 2. sedang } \\
\text { 1. tidak baik }\end{array}$ & Ordinal \\
\hline
\end{tabular}

4. Variabel Terikat

Pencatatan Rekam Medis adalah keadaan pencatatan di dalam berkas rekam medis tentang dataPencatatan data keadaan pasien, tindakan, Rekam Medis pengobatan dll yang menjadi tanggung jawab dokter yang

1. Lengkap

2. Tidak Nominal lengkap inap

2. Menggunakan check list kelengkapan pencatatan rekam medis untuk perilaku dokter dalam pencatatan rekam medis.

a. Penyusunan lembar check list kelengkapan pencatatan rekam medis untuk pengumpulan data bersumber dari kelengkapan isian rekam medis menurut 
Permenkes No. 269/2008 dan disesuaikan juga dengan penerapan di RSUD Dr. RM Djoelham yaitu dalam buku pedoman rekam medis RSUD Dr. RM Djoelham tahun 2017.

b. Penilaian check list adalah sebagai berikut nilai 0 diberikan untuk jawaban yang tidak diisi semestinya dan nilai 100 diberikan untuk jawaban yang diisi semestinya.

\section{Data Sekunder}

Data-data sekunder yang diambil untuk penelitian ini di peroleh dari Bagian Perencanaan dan Rekam Medis RSUD Dr. RM Djoelham Binjai berupa laporan evaluasi ketidaklengkapan pengisian catatan medis (KLPCM) bulan Oktober 2020.

F. Analisis Data

Data yang diperoleh dianalisa dengan beberapa uji statistik menggunakan program komputer.

a. Analisa Univariat

Analisa univariat dilakukan untuk melihat gambaran dan karakteristik setiap variabel independen (bebas) yaitu: faktor predisposisi (pengetahuan, sikap), faktor pendorong (dukungan petugas lain) dan faktor pendukung (fasilitas dan sarana, peraturan) menentukan terbentuknya perilaku. Sedangkan untuk veriabel dependen (terikat) meliputi pencatatan rekam medis di RSUD Dr. RM Djoelham Binjai.

b. Analisa Bivariat

Analisa bivariat dilakukan untuk menguji dan menganalisa masing-masing pengaruh antara faktor predisposisi (pengetahuan, sikap), faktor pendorong (dukungan petugas lain), faktor pendukung fasilitas dan sarana, peraturanperaturan dengan kelengkapan pencatatan rekam medis di RSUD Dr. RM Djoelham Binjai dengan menggunakan uji Chi-Square test.

c. Analisa Multivariat

Analisa multivariat dilakukan untuk mengetahui variabel bebas yang paling berpengaruh faktor predisposisi (pengetahuan, sikap), faktor pendorong (dukungan petugas lain) dan faktor pendukung (fasilitas dan sarana, peraturan) dengan kelengkapan pencatatan rekam medis di RSUD Dr. RM Djoelham Binjai. Dilakukan uji regresi, karena menurut Green (2005), faktor predisposisi (pengetahuan, sikap), faktor pendorong (dukungan petugas lain) dan faktor pendukung (fasilitas dan sarana, peraturan) menentukan terbentuknya perilaku. Peneliti ingin mengetahui bagaimana hubungan causal ataupun pengaruh dari faktor-faktor predisposisi, faktor pendorong dan faktor pendukung terhadap pencatatan rekam medis. Oleh karena variabel bebas lebih dari 2 (ada 5) maka digunakan uji regresi logistik berganda.

\section{HASIL DAN PEMBAHASAN}

\subsection{Hasil}

\section{Analisis Univariat}

Tabel 2. Karakteristik Responden Berdasarkan Kelengkapan Pencatatan Rekam

Medis di RSUD Dr. RM Djoelham Binjai

\begin{tabular}{cccc}
\hline No & Pencatatan Rekam Medis & f & Persentase \\
\hline 1 & Tidak Lengkap & 12 & 41,4 \\
\hline 2 & Lengkap & 17 & 58,6 \\
\hline & Total & $\mathbf{2 9}$ & $\mathbf{1 0 0 , 0}$
\end{tabular}

Berdasarkan hasil peneltian dapat dilihat bahwa pencatatan rekam medis lengkap sebanyak 17 orang $(58,6 \%)$. Responden yang pencatatan rekam medis tidak lengkap 
sebanyak 12 orang $(41,4 \%)$. Dari hasil penelitian didapatkan pencatatan rekam medis yang lebih dominan adalah lengkap.

Tabel 3. Karakteristik Responden Berdasarkan Pengetahuan Di RSUD Dr. RM Djoelham Binjai

\begin{tabular}{cccc}
\hline No & Pengetahuan & f & Persentase \\
\hline 1 & Baik & 18 & 62,1 \\
\hline 2 & Sedang & 11 & 37,9 \\
\hline & Total & $\mathbf{2 9}$ & $\mathbf{1 0 0 , 0}$ \\
\hline
\end{tabular}

Berdasarkan berdasarkan hasil peneltian dapat dilihat bahwa berdasarkan Pengetahuan didapatkan baik sebanyak 18 orang $(62,1 \%)$. Dan responden pengetahuan sedang sebanyak 11 orang $(37,9 \%)$. Dari hasil penelitian didapatkan berdasarkan pengetahuan yang lebih dominan baik.

Tabel 4. Karakteristik Responden Berdasarkan Sikap di RSUD Dr. RM Djoelham Binjai

\begin{tabular}{cccc}
\hline No & Sikap & f & Persentase \\
\hline 1 & Sedang & 9 & 31,0 \\
\hline 2 & Tidak Baik & 20 & 69,0 \\
\hline & Total & $\mathbf{2 9}$ & $\mathbf{1 0 0 , 0}$ \\
\hline
\end{tabular}

Berdasarkan berdasarkan hasil peneltian dapat dilihat bahwa berdasarkan Sikap didapatkan sedang sebanyak 9 orang $(31,0 \%)$. Dan responden Sikap sedang sebanyak 20 orang $(69,0 \%)$. Dari hasil penelitian didapatkan berdasarkan Sikap yang lebih dominan tidak baik.

Tabel 5. Karakteristik Responden Berdasarkan Dukungan Petugas lainnya di RSUD Dr. RM Djoelham Binjai

\begin{tabular}{cccc}
\hline No & Dukungan Petugas lainnya & f & Persentase \\
\hline 1 & Tidak Baik & 5 & 17,2 \\
\hline 2 & Sedang & 24 & 82,8 \\
\hline & Total & $\mathbf{2 9}$ & $\mathbf{1 0 0 , 0}$
\end{tabular}

Berdasarkan berdasarkan hasil peneltian dapat dilihat bahwa berdasarkan dukungan petugas lainnya didapatkan tidak baik sebanyak 5 orang $(17,2 \%)$. Dan responden dukungan petugas lainnya sedang sebanyak 24 orang $(82,8 \%)$. Dari hasil penelitian didapatkan berdasarkan dukungan petugas Lainnya yang lebih dominan Sedang.

Tabel 6. Karakteristik Responden Berdasarkan Fasilitas dan Sarana di RSUD Dr. RM Djoelham Binjai

\begin{tabular}{cccc}
\hline No & Fasilitas dan Sarana & f & Persentase \\
\hline 1 & Tidak Baik & 6 & 20,7 \\
\hline 2 & Sedang & 18 & 62,1 \\
\hline 3 & Baik & 5 & 17,2 \\
\hline & Total & $\mathbf{2 9}$ & $\mathbf{1 0 0 , 0}$ \\
\hline
\end{tabular}

Berdasarkan berdasarkan hasil penelitian dapat dilihat bahwa berdasarkan fasilitas dan sarana lainnya didapatkan tidak baik sebanyak 6 orang $(20,7 \%)$. Responden fasilitas dan sarana lainnya sedang sebanyak 18 orang $(62,1 \%)$. Dan responden Fasilitas dan sarana lainnya baik sebanyak 5 orang $(17,2 \%)$. Dari hasil penelitian didapatkan berdasarkan fasilitas dan sarana Lainnya yang lebih dominan sedang. 
Tabel 7. Karakteristik Responden Berdasarkan Peraturan-Peraturan di RSUD Dr. RM Djoelham Binjai

\begin{tabular}{cccc}
\hline No & Peraturan & f & Persentase \\
\hline 1 & Tidak Baik & 18 & 62,1 \\
\hline 2 & Sedang & 11 & 37,9 \\
\hline & Total & $\mathbf{2 9}$ & $\mathbf{1 0 0 , 0}$
\end{tabular}

Berdasarkan hasil peneltian dapat dilihat bahwa berdasarkan peraturan lainnya didapatkan tidak baik sebanyak 18 orang $(62,1 \%)$. Dan responden peraturan lainnya sedang sebanyak 11 orang $(37,9 \%)$. Dari hasil penelitian didapatkan berdasarkan peraturan lainnya yang lebih dominan tidak baik.

\section{Analisis Bivariat}

Tabel 8. Tabulasi Silang Hubungan Pengetahuan Terhadap Pencatatan Rekam Medis di RSUD Dr. RM Djoelham Binjai

\begin{tabular}{|c|c|c|c|c|c|c|c|c|}
\hline \multirow{3}{*}{ No } & \multirow{3}{*}{ Pengetahuan } & \multicolumn{4}{|c|}{ Pencatata Rekam Medis } & \multirow{2}{*}{\multicolumn{2}{|c|}{ Jumlah }} & \multirow{3}{*}{ p-value } \\
\hline & & \multicolumn{2}{|c|}{ Tidak Lengkap } & \multicolumn{2}{|c|}{ Lengkap } & & & \\
\hline & & $\mathbf{f}$ & $\%$ & $\mathbf{f}$ & $\%$ & $\mathbf{f}$ & $\%$ & \\
\hline 1 & Baik & 8 & 27,6 & 10 & 34,5 & 18 & 62,1 & \multirow{3}{*}{0,001} \\
\hline 2 & Sedang & 4 & 13,8 & 7 & 24,1 & 11 & 37,9 & \\
\hline & Jumlah & 12 & 41,4 & 17 & 58,6 & 29 & 100 & \\
\hline
\end{tabular}

Berdasarkan tabel 8 menunjukkan bahwa hasil tabulasi silang pengetahuan terhadap pencatatan rekam medis didapatkan dari 29 orang dengan jumlah pengetahuan baik sebanyak 18 orang $(62,1 \%)$, mayoritas pengetahuan baik pencatatan rekam medis lengkap sebanyak 10 orang $(34,5 \%)$. Minoritas pengetahuan baik pencatatan rekam medis tidak lengkap sebanyak 8 orang $(27,6 \%)$. Pengetahuan sedang dengan jumlah 11 orang $(37,9 \%)$, mayoritas pengetahuan sedang pencatatan rekam medis lengkap sebanyak 7 orang $(24,1 \%)$, sedangkan pengetahuan sedang pencatatan rekam medis tidak lengkap sebanyak 4 orang $(13,8 \%)$. Hasil uji statistik menggunakan uji chi-square menunjukkan bahwa nilai $p$-value sebesar $0,001<0,05$ yang berarti ada pengaruh antara pengetahuan terhadap pencatatan rekam medis di RSUD Dr. RM Djoelham Binjai.

Tabel 9. Tabulasi Silang Hubungan Sikap Terhadap Pencatatan Rekam Medis di RSUD Dr. RM Djoelham Binjai

\begin{tabular}{|c|c|c|c|c|c|c|c|c|}
\hline \multirow{3}{*}{ No } & \multirow{3}{*}{ Sikap } & \multicolumn{4}{|c|}{ PencatataRekam Medis } & \multirow{2}{*}{\multicolumn{2}{|c|}{ Jumlah }} & \multirow{3}{*}{$p$-value } \\
\hline & & \multicolumn{2}{|c|}{ Tidak Lengkap } & \multicolumn{2}{|c|}{ Lengkap } & & & \\
\hline & & $\mathbf{f}$ & $\%$ & f & $\%$ & $\mathbf{f}$ & $\%$ & \\
\hline 1 & Tidak Baik & 4 & 13,8 & 5 & 17,2 & 9 & 31,0 & 0,002 \\
\hline 2 & Sedang & 8 & 27,6 & 12 & 41,4 & 10 & 69,0 & \\
\hline & Jumlah & 12 & 41,4 & 17 & 58,6 & 29 & 100 & \\
\hline
\end{tabular}

Berdasarkan tabel 9 menunjukkan bahwa hasil tabulasi silang Sikap terhadap pencatatan rekam medis didapatkan dari 29 orang dengan jumlah sikap tidak baik sebanyak 9 orang $(31,0 \%)$ mayoritas sikap tidak baik pencatatan rekam medis lengkap sebanyak 5 orang $(17,2 \%)$. Minoritas sikap tidak baik pencatatan rekam medis tidak lengkap 4 orang $(13,8 \%)$. Sikap sedang dengan jumlah 10 orang $(69,0 \%)$, mayoritas sikap sedang pencatatan rekam medis lengkap sebanyak 12 orang $(41,4 \%)$ sedangkan pengetahuan sedang pencatatan rekam medis tidak lengkap sebanyak 8 orang $(27,6 \%)$. Hasil uji statistik menggunakan uji chi-square menunjukkan bahwa nilai p-value sebesar 0,002<0,05 yang berarti ada pengaruh antara sikap terhadap pencatatan rekam medis di RSUD Dr. RM Djoelham Binjai. 
Tabel 10. Tabulasi Silang Hubungan Dukungan Tenaga lainnya Terhadap Pencatatan Rekam Medis di RSUD Dr. RM Djoelham Binjai

\begin{tabular}{|c|c|c|c|c|c|c|c|c|}
\hline \multirow{3}{*}{ No } & \multirow{3}{*}{$\begin{array}{c}\text { Dukungan Tenaga } \\
\text { lainnya }\end{array}$} & \multicolumn{4}{|c|}{ PencatatanRekam Medis } & \multirow{2}{*}{\multicolumn{2}{|c|}{ Jumlah }} & \multirow{3}{*}{$p$-value } \\
\hline & & \multicolumn{2}{|c|}{ Tidak Lengkap } & \multicolumn{2}{|c|}{ Lengkap } & & & \\
\hline & & $\mathbf{f}$ & $\%$ & $\mathbf{f}$ & $\%$ & $\mathbf{f}$ & $\%$ & \\
\hline 1 & Tidak Baik & 1 & 3,4 & 4 & 13,8 & 5 & 17,2 & \multirow{3}{*}{0,000} \\
\hline 2 & Sedang & 11 & 37,9 & 13 & 44,8 & 24 & 82,8 & \\
\hline & Jumlah & 12 & 41,4 & 17 & 58,6 & 29 & 100 & \\
\hline
\end{tabular}

Berdasarkan tabel 10 menunjukkan bahwa hasil tabulasi silang dukungan tenaga lainnya terhadap pencatatan rekam medis didapatkan dari 29 orang dengan jumlah dukungan tenaga lainnya tidak baik sebanyak 5 orang $(17,2 \%)$. Mayoritas dukungan tenaga lainnya tidak baik pencatatan rekam medis lengkap sebanyak 4 orang $(13,8 \%)$. Minoritas dukungan tenaga lainnya sedang pencatatan rekam medis tidak lengkap sebanyak 24 orang $(82,8 \%)$. Mayoritas dukungan tenaga lainnya sedang pencatatan rekam medis lengkap sebanyak 13 orang $(44,8 \%)$ sedangkan dukungan tenaga lainnya sedang pencatatan rekam medis tidak lengkap sebanyak 11 orang $(37,9 \%)$. Hasil uji statistik menggunakan uji chisquare menunjukkan bahwa nilai $p$-value sebesar $0,000<0,05$ yang berarti ada pengaruh antara dukungan tenaga lainnya terhadap pencatatan rekam medis di RSUD Dr. RM Djoelham Binjai.

Tabel 11. Tabulasi Silang Fasilitas dan Sarana Terhadap Pencatatan Rekam Medis di RSUD Dr. RM Djoelham Binjai

\begin{tabular}{|c|c|c|c|c|c|c|c|c|}
\hline \multirow{3}{*}{ No } & \multirow{3}{*}{$\begin{array}{c}\text { Fasilitas dan } \\
\text { sarana }\end{array}$} & \multicolumn{4}{|c|}{ Pencatatan Rekam Medis } & \multirow{2}{*}{\multicolumn{2}{|c|}{ Jumlah }} & \multirow{3}{*}{ p-value } \\
\hline & & \multicolumn{2}{|c|}{ Tidak Lengkap } & \multicolumn{2}{|c|}{ Lengkap } & & & \\
\hline & & $\mathbf{f}$ & $\%$ & $\mathbf{f}$ & $\%$ & $\mathbf{f}$ & $\%$ & \\
\hline 1 & Tidak Baik & 3 & 10,3 & 3 & 10,3 & 6 & 20,7 & \multirow{4}{*}{0,002} \\
\hline 2 & Sedang & 6 & 20,7 & 12 & 41,4 & 18 & 62,1 & \\
\hline 3 & Baik & 3 & 10,3 & 2 & 6,9 & 5 & 17,2 & \\
\hline & Jumlah & 12 & 41,4 & 17 & 58,6 & 29 & 100 & \\
\hline
\end{tabular}

Berdasarkan tabel 11 menunjukkan bahwa hasil tabulasi silang fasilitas dan sarana lainnya terhadap pencatatan rekam medis didapatkan dari 29 orang dengan jumlah fasilitas dan sarana tidak baik sebanyak 6 orang $(20,7 \%)$ mayoritas fasilitas dan sarana tidak baik pencatatan rekam medis tidak lengkap sebanyak 3 orang (10,3\%). Mayoritas fasilitas dan sarana sedang pencatatan rekam medis lengkap sebanyak 12 orang $(41,4 \%)$ sedangkan fasilitas dan sarana sedang pencatatan rekam medis tidak lengkap sebanyak 6 orang $(20,7 \%)$, dan mayoritas fasilitas dan sarana baik pencatatan rekam medis sebanyak 5 orang $(17,2 \%)$. Hasil uji statistik menggunakan uji chi-square menunjukkan bahwa nilai $p$-value sebesar 0,002<0,05 yang berarti ada pengaruh antara fasilitas dan sarana terhadap pencatatan rekam medis di RSUD Dr. RM Djoelham Binjai.

Tabel 12. Tabulasi Silang Hubungan Peraturan Terhadap Pencatatan Rekam Medis di RSUD Dr. RM Djoelham Binjai

\begin{tabular}{|c|c|c|c|c|c|c|c|c|}
\hline \multirow{3}{*}{ No } & \multirow{3}{*}{ Peraturan } & \multicolumn{4}{|c|}{ Pencatatan Rekam Medis } & \multirow{2}{*}{\multicolumn{2}{|c|}{ Jumlah }} & \multirow{3}{*}{$p$-value } \\
\hline & & \multicolumn{2}{|c|}{ Tidak Lengkap } & \multicolumn{2}{|c|}{ Lengkap } & & & \\
\hline & & $\mathbf{f}$ & $\%$ & $\mathbf{f}$ & $\%$ & $\mathbf{f}$ & $\%$ & \\
\hline 1 & Tidak Baik & 8 & 27,6 & 10 & 34,5 & 18 & 62,1 & \multirow{3}{*}{0,007} \\
\hline 2 & Sedang & 4 & 13,8 & 7 & 24,1 & 11 & 37,9 & \\
\hline & Jumlah & 12 & 41,4 & 17 & 58,6 & 29 & 100,0 & \\
\hline
\end{tabular}


Berdasarkan tabel 12 menunjukkan bahwa hasil tabulasi silang peraturan terhadap pencatatan rekam medis didapatkan dari 29 orang dengan jumlah peraturan tidak baik sebanyak 18 orang $(62,1 \%)$, mayoritas peraturan tidak baik pencatatan rekam medis lengkap sebanyak 10 orang $(34,5 \%)$. Minoritas peraturan sedang pencatatan rekam medis tidak lengkap sebanyak 8 orang $(27,6 \%)$. Mayoritas peraturan sedang pencatatan rekam medis lengkap sebanyak 11 orang $(37,9 \%)$ sedangkan peraturan sedang pencatatan rekam medis tidak lengkap sebanyak 4 orang $(13,8 \%)$. Hasil uji statistik menggunakan uji chisquare menunjukkan bahwa nilai p-value sebesar 0,007<0,05 yang berarti ada pengaruh antara peraturan terhadap pencatatan rekam medis di RSUD Dr. RM Djoelham Binjai.

\section{Analisis Multivariat}

Tabel 13. Hasil Uji Regresi Logistik Ganda Tahap Pertama

\begin{tabular}{lccc}
\hline \multicolumn{1}{c}{ Variabel } & B & Sig. & Exp(B) \\
\hline Pengetahuan & 1,393 & 0,028 & 4,026 \\
\hline Sikap & 2,402 & 0,023 & 11,049 \\
\hline Dukungan petugas lain & -2.637 & 0,013 & 0,072 \\
\hline Fasilitas dan sarana & 2,207 & 0,026 & 9,431 \\
\hline Peraturan & 2,244 & 0,269 & 9,091 \\
\hline Konstanta & $-5,261$ & 0,006 & 0,005 \\
\hline
\end{tabular}

Berdasarkan tabel di atas menunjukkan bahwa dari 5 variabel yang diuji regresi logistik berganda pada tahap pertama terlihat variabel yang memiliki nilai p-value $>0,05$ dan yang terbesar adalah status peraturan $(\mathrm{p}=0,269)$. Dan selanjutnya variabel peraturan dikeluarkan dari pemodelan pada regresi logistik tahap kedua, hasilnya adalah sebagai berikut :

Tabel 14. Hasil Uji Regresi Logistik Ganda Tahap Kedua

\begin{tabular}{lccc}
\hline \multicolumn{1}{c}{ Variabel } & B & Sig. & $\operatorname{Exp}(\mathbf{B})$ \\
\hline Pengetahuan & 1,305 & 0,032 & 3,688 \\
\hline Sikap & 2.444 & 0,018 & 11,522 \\
\hline Dukungan petugas lain & $-2,782$ & 0,008 & 0,062 \\
\hline Fasilitas dan sarana & 2,489 & 0,016 & 12,048 \\
\hline Konstanta & $-5,816$ & 0,002 & 0,003 \\
\hline
\end{tabular}

Berdasarkan hasil uji regresi logistik berganda tersebut nilai signifikan model secara bersama-sama diperoleh sebesar $0,002<0,05$ yang berarti bahwa keempat variabel yang dijadikan model dalam penelitian ini memiliki pengaruh yang signifikan dengan pencatatan rekam medik. Sehingga dapat disimpulkan bahwa faktor yang paling besar pengaruhnya terhadap pencatatan rekam medis adalah dukungan petugas lain.

\subsection{Pembahasan}

\section{Hubungan Karakteristik Responden Dengan Pencatatan Rekam Medis}

Tingkat pengetahuan seseorang mengenai informasi baik atau buruk yang didapatkan dipengaruhi oleh pendidikan, pengaruh orang terdekat atau yang berpengaruh ditempat Ibu berdomisili, kepercayaan yang dianut dan pengalaman. Hasil jawaban responden bila dihubungkan dengan kondisi masalah pencatatan dikalangan medis menunjukkan bahwa konsistensi dari petugas kesehatan sudah baik dalam menyampaikan informasi yang tepat kepada masyarakat [9].

Hasil penelitian tersebut sejalan dengan penelitian Devi Pramita Sari, dengan judul "Hubungan Antara Pengetahuan Perawat Tentang Rekam Medis Dan Dokumentasi Keperawatan Dengan Kelengkapan Pencatatan Dokumentasi Keperawatan Di Klinik Mta Surakarta 2019'. Diperoleh hasil bahwa ada hubungan pengetahuan ( $\mathrm{p}$-value $=0,001<\alpha=$ 
0,05). Dengan demikian dapat disimpulkan bahwa ada hubungan antara pengetahuan perawat tentang rekam medis dan dokumentasi keperawatan dengan kelengkapan pencatatan dokumentasi keperawatan di Klinik MTA Surakarta 2019 [10].

Berdasarkan hasil penelitian dan teori diatas, menurut temuan peneliti dengan pengetahuan yang tinggi belum tentu memiliki kesadaran dan keinginan melakukan pencatatan rekam medis. Hal ini dipengaruhi dengan kurangnya pengetahuan dan kesadaran dokter dalam pencatatan rekam medis.

\section{Tabulasi Silang Hubungan Sikap Terhadap Pencatatan Rekam Medis di RSUD Dr. RM Djoelham Binjai}

Menurut Peraturan Pemerintah No.32/1996 rekam medis harus dibuat oleh Perawat yang merawat pasien, sikap adalah merupakan reaksi yang masih tertutup, hanya dapat ditafsirkan dari perilaku yang tampak. Pendapat lain sikap merupakan respon evaluatif didasarkan pada proses evaluasi diri yang disimpulkan berupa pilihan positif atau negatif yang kemudian mengkristal sebagai potensi reaksi terhadap obyek, Secara definitif sikap berarti suatu keadaan jiwa (mental) dan keadaan pikir (neural) yang dipersiapkan untuk memberikan tanggapan terhadap suatu obyek yang diorganisasi melalui pengalaman serta mempengaruhi secara langsung atau tidak langsung pada perilaku [11].

Hasil penelitian tersebut sejalan dengan penelitian Ali Sabela Hasibuan, dengan "Sikap Petugas Terhadap Pengisian Rekam Medis Rawat Inap Di Rumah Sakit Sinar Husni Tahun 2017. Diperoleh hasil bahwa ada hubungan sikap (P-Value $=0,007<\alpha=0,05$ ). Dengan demikian dapat disimpulkan bahwa ada hubungan antara sikap perawat terhadap pengisian rekam medis rawat inap di rumah sakit sinar husni tahun 2017 [12].

Berdasarkan penelitian dan teori diatas, menurut temuan peneliti bahwa pada umumnya sikap petugas rekam medis yang baik yakni disebabkan karena peran dan fungsi penginderaan dimana seseorang dapat menerima stimulus dari suatu object tertentu, dari yang tidak tahu menjadi tahu atau muncul pengetahuan baru terhadap suatu objek tertentu, dan yang tidak baik yakni menyebabkan kelambatan dan kesalahan dalam pengisian indentitas pasien tersebut.

\section{Tabulasi Silang Hubungan Dukungan Tenaga lainnya Terhadap Pencatatan Rekam Medis di RSUD Dr. RM Djoelham Binjai}

Penelitian ini sesuai dengan penelitian Renny Afriany dengan judul "Analisis Dan Perancangan Sistem Informasi Rekam Medis di Rumah Sakit TK. IV Dr. Bratanata Jambi" diperoleh hasil bahwa ada hubungan sikap ( $\mathrm{P}-\mathrm{Value}=0,007<\mathrm{A}=0,05$ ). Dengan demikian dapat disimpulkan bahwa ada hubungan antara dukungan tenaga lainnya terhadap pengisian rekam medis rawat inap di Rumah Sakit TK. IV Dr. Bratanata Jambi [13].

Berdasarkan penelitian dan terori diatas, menurut temuan peneliti bahwa pada umumnya dukungan tenaga lainnya petugas rekam medis yang sedang yakni disebabkan karena kelambatan dan kesalahan dalam pengisian indentitas pasien tersebut semakin baik dukungan dari tenaga lainnya maka semakin tercapailah pencatatan rekam medis yang dilakukan.

\section{Silang Fasilitas dan Sarana Terhadap Pencatatan Rekam Medis di RSUD Dr. RM Djoelham Binjai}

Penelitian Cut Asmaul Husna dengan judul Analysis Services Medical Record In Bhayangkara Hospitals Kediri-East Java diperoleh hasil bahwa ada hubungan yang bermakna antara fasilitas dan sarana ( $\mathrm{p}$-value $=0,008<\alpha=0,05$ ). Hasil penelitian terkait variabel fasilitas dan sarana pelayanan rekam medis menunjukkan bahwa fasilitas dan sarana dalam kategori sedang. Hal ini menujukkan bahwa RS X Kediri telah memenuhi 
standar persyaratan Kemenkes terkait sarana prasarana. Penelitian terkait sarana prasarana juga dilakukan pada RSU Bina Kasih Ambarawa yang menunjukkan bahwa pengembangan sistem informasi mendukung perubahan kualitas informasi dan pelayanan [14].

Berdasarkan penelitian dan terori diatas, menurut temuan peneliti bahwa fasilitas dan sarana pencatatan yang disediakan dalam kategori sedang hal ini disebabkan karena selama ini proses pencatatan yang dilakukan jarang terhambat karena sarana pencatatan yang kurang atau sulit dipahami, misalnya disetiap ruangan tersedia formulir rekam medis secara cukup dan ada 1 komputer yang terhubung dengan database yang dapat dijadikan sebagai sarana untuk melakukan pencatatan rekam medis.

\section{Tabulasi Silang Hubungan Peraturan Terhadap Pencatatan Rekam Medis di RSUD Dr. RM Djoelham Binjai.}

Peraturan dalam pelayanan merupakan alur pemberian pelayanan rekam medis yang diberikan tenaga kesehatan untuk meminjam data pasien yang telah tersimpan di instalasi rekam medis. Peraturan tersebut diberikan agar proses pelayanan peminjaman berkas dapat tercatat dan dapat dipertanggung jawabkan dengan baik. SOP pencatatan adalah tata cara pencatatan yang harus dilakukan oleh tenaga kesehatan dalam memberikan catatan tindakan dan siapa saja yang berhak memberikan catatan rekam medis Berdasarkan hasil pengamatan yang dilakukan setiap ruangan memiliki print out SOP pencatatan rekam medis, tetapi semua perawat pernah mendapatkan informasi melalui pelatihan pada saat awal bekerja tentang tata cara pengisian dan penyimpanan rekam medis [15].

Penelitian Hafid Hutama dengan judul "Evaluasi Mutu Rekam Medis di Rumah Sakit PKU 1 Muhammadiyah Yogyakarta" diperoleh hasil bahwa ada hubungan yang bermakna antara peraturan $(\mathrm{p}$-value $=0,008<\alpha=0,05)$. Hasil penelitian terkait variabel peraturan pelayanan rekam medis menunjukkan bahwa Peraturan dalam kategori tidak baik syaratan Kemenkes terkait peraturan. Penelitian terkait peraturan juga dilakukan pada Rumah Sakit PKU 1 Muhammadiyah Yogyakarta Ambarawa yang menunjukkan bahwa peraturan yang lain dalam pengembangan sistem informasi mendukung perubahan kualitas informasi dan pelayanan [16].

Berdasarkan penelitian dan terori diatas, menurut temuan peneliti bahwa peraturan yang disediakan dalam kategori tidak baik hal ini disebabkan karena selama ini proses peraturan yang dilakukan ada hal yang kurang baik dilakukan karena peraturan yang sudah dibuat namun tidak diberikan sanksi jika tidak dilakukan baik akan membuat dokter melakukan pencatatan rekam medis secara baik, misalnya jika dokter tidak melakukan pencatatan rekam medis dengan baik dan lengkap akan dikenakan sangsi yang berlaku, hal ini akan membuat efek jera pada dokter yang enggan melakukan pencatatan secara baik dan lengkap.

\section{Hubungan Pengetahuan, Sikap, Dukungan Petugas Lainnya, Fasilitas Dan Sarana, Dan Peraturan Terhadap Perilaku Dokter Dalam Pencatatan Rekam Medis di RSUD Dr. RM Djoelham Binjai.}

Berdasarkan hasil penelitian dan teori diatas, menurut temuan peneliti dengan pengetahuan yang tinggi belum tentu memiliki kesadaran dan keinginan melakukan pencatatan rekam medis. Hal ini dipengaruhi dengan kurangnya pengetahuan dan kesadaran dokter dalam pencatatan rekam medis. Sedangkan sikap petugas rekam medis yang baik yakni disebabkan karena peran dan fungsi penginderaan dimana seseorang dapat menerima stimulus dari suatu objek tertentu, dari yang tidak tahu menjadi tahu atau muncul pengetahuan baru terhadap suatu objek tertentu, dan yang tidak baik yakni menyebabkan kelambatan dan kesalahan dalam pengisian indentitas pasien tersebut. Dukungan tenaga lainnya yakni menyebabkan kelambatan dan kesalahan dalam pengisian 
indentitas pasien tersebut semakin baik dukungan dari tenaga lainnya maka semakin tercapailah pencatatan rekam medis yang dilakukan. Fasilitas dan sarana pencatatan yang disediakan dalam kategori sedang hal ini disebabkan karena selama ini proses pencatatan yang dilakukan jarang terhambat karena sarana pencatatan yang kurang atau sulit dipahami, misalnya disetiap ruangan tersedia formulir rekam medis secara cukup dan ada 1 komputer yang terhubung dengan database yang dapat dijadikan sebagai sarana untuk melakukan pencatatan rekam medis. Peraturan yang sudah dibuat harus diikuti pemberian sanksi, misalnya jika dokter tidak melakukan pencatatan rekam medis dengan baik dan lengkap akan dikenakan sanksi yang berlaku, hal ini akan membuat efek jera pada dokter yang enggan melakukan pencatatan secara baik dan lengkap.

\section{KESIMPULAN}

Berdasarkan dari hasil penelitian yang dilakukan di RSUD Dr. RM Djoelham Binjai, maka dapat disimpulkan sebagai berikut:

1. Ada pengaruh antara pengetahuan terhadap pencatatan rekam medis di RSUD Dr. RM Djoelham Binjai. Hasil uji statistik menggunakan uji chi-square menunjukkan bahwa nilai $p$-value sebesar $0,001<0,05$.

2. Ada pengaruh antara sikap terhadap pencatatan rekam medis di RSUD Dr. RM Djoelham Binjai. Hasil uji statistik menggunakan uji chi-square menunjukkan bahwa nilai $p$-value sebesar $0,002<0,05$.

3. Ada pengaruh antara dukungan tenaga lainnya terhadap pencatatan rekam medis di RSUD Dr. RM Djoelham Binjai. Hasil uji statistik menggunakan uji chi-square menunjukkan bahwa nilai $p$-value sebesar $0,000<0,05$.

4. Ada pengaruh antara fasilitas dan sarana terhadap pencatatan rekam medis di RSUD Dr. RM Djoelham Binjai. Hasil uji statistik menggunakan uji chi-square menunjukkan bahwa nilai $p$-value sebesar $0,002<0,05$.

5. Ada pengaruh antara peraturan-peraturan terhadap pencatatan rekam medis di RSUD Dr. RM Djoelham Binjai. Hasil uji statistik menggunakan uji chi-square menunjukkan bahwa nilai $p$-value sebesar $0,007<0,05$.

6. Hasil penelitian analisis multivariat diperoleh bahwa variabel pengetahuan, sikap, dukungan tenaga lainnya, fasilitas dan sarana, dan peraturan-peraturan ada pengaruh terhadap pencatatan rekam medis dan faktor yang paling berpengaruh adalah adanya dukungan petugas lain terhadap pencatatan rekam medis di RSUD Dr. RM Djoelham Binjai.

\section{REFERENCES}

[1]. Indonesia KK. Manual rekam medis. Jakarta Kons Kedokt Indones. 2006;

[2]. Harsono H, Sugiharto S. Representasi Kualitas Informasi Dokumen Rekam Medis Berbasis Permenkes RI Nomor 269/MENKES/PER/III/2008 di Klinik Pratama Surya Medika Semarang. J Ilmu dan Teknol Kesehat. 2020;11(2).

[3]. BAB I. Berdasarkan Permenkes RI No. 269/Menkes/Per/III/2008 yang dimaksud rekam medis adalah berkas yang berisi catatan dan dokumen antara lain identitas pasien, hasil pemeriksaan, pengobatan yang telah diberikan, serta tindakan dan pelayanan lain yang telah dib.

[4]. Ulfa HM. Analisis Unsur Manajemen dalam Pengolahan Rekam Medis di Rumah Sakit TNI AU Lanud Roesmin Nurjadin. Kesmars. 2018;1(1):20-5.

[5]. Simanjuntak E, Khairunisah K. Gambaran Pengetahuan Petugas Rekam Medis Terhadap Indikator Pelayanan Rawat Inap di Rumah Sakit Umum Pusat H. Adam Malik Medan Tahun 2019. Pros SINTAKS 2019. 2019;1(1):526-31. 
[6]. Wirajaya MK, Nuraini N. Faktor Faktor yang Mempengaruhi Ketidaklengkapan Rekam Medis Pasien pada Rumah Sakit di Indonesia. J Manaj Inf Kesehat Indones. 2019;7(2):165.

[7]. Wariyanti AS, Harjanti H, Sugiarsi S. Potret Kelengkapan Rekam Medis Puskesmas Sebelum dan Setelah Akreditasi. J Manaj Inf Kesehat Indones. 2019;7(2):157.

[8]. Kurniawan ID. Implementasi Peraturan Walikota Nomor 6 Tahun 2017 Tentang Kawasan Tanpa Rokok Di RSUD Dr. RM Djoelham Kota Binjai Skripsi. 2019.

[9]. Wiguna AS, Fahrani A. Tingkat Pengetahuan Petugas Rekam Medis Terhadap Pelaksanaan Penyusutan Dan Pemusnahan Berkas Rekam Medis Dirumah Sakit Umum Madani Medan Tahun 2018. Jurnal Ilmiah Perekam dan Informasi Kesehatan Imelda. 2019;4(1):537-44.

[10]. Sari DP, Siwi GR. Hubungan Antara Pengetahuan Perawat Tentang Rekam Medis dan Dokumentasi Keperawatan Dengan Kelengkapan Pencatatan Dokumentasi Keperawatan di Klinik MTA Surakarta 2019. Infokes J. 2019;9(1):45-9.

[11]. Di rumah prdanp. Sikap mengenab keselamatan.

[12]. Hasibuan AS, Siburian MW. Sikap Petugas Terhadap Pengisian Rekam Medis Rawat Inap Di Rumah Sakit Sinar Husni Tahun 2017. Jurnah Ilmiah Perekam dan Informasi Kesehatan Imelda. 2018;3(1):363-9.

[13]. Afriany R, Purnama B. Analisis dan Perancangan Sistem Informasi Rekam Medis di Rumah Sakit Tk. IV dr. Bratanata Jambi. J Manaj Sist Inf. 2016;1(2):147-58.

[14]. Nugraheni R. Analisis Pelayanan Rekam Medis di Rumah Sakit X Kediri Jawa Timur. J Wiyata Penelit Sains dan Kesehat. 2017;2(2):169-75.

[15]. Hidayati M, Rahmatika W. Pengaruh peminjaman rekam medis rawat jalan terhadap mutu instalasi rekam medis di upt rsud lembang. J infokes (Informasi Kesehatan). 2019;3(2):55-68.

[16]. Susanto A, Sri Sugiarsi SKM. Penerapan Manajemen Mutu Pelayanan Di Unit Rekam Medis Rumah Sakit PKU Muhammadiyah Surakarta. Universitas Muhammadiyah Surakarta; 2016.

\section{BIOGRAPHIES OF AUTHORS}

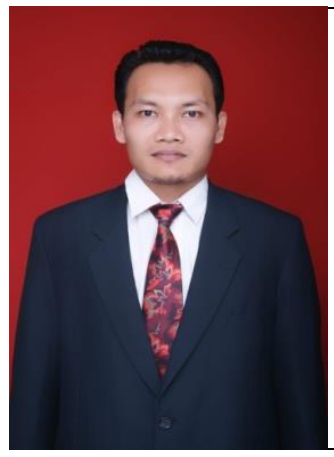

Giyatno, Gelar Ahli madya perekam medis dan informasi kesehatan diperoleh dari APIKES Bhakti Mulia pada Tahun 2005. Sarjana Komputer diperoleh dari Universitas Panca Budi Jurusan Teknik Informasi pada Tahun 2011. Sarjana Kesehatan Kesehatan diperoleh dari STIKes Helvetia Medan pada Tahun 2014. Saat ini aktif sebagai pegawai pengajar Program Studi D-III Perekam Medis dan Informasi Kesehatan Universitas Imelda Medan 